\title{
Bacterial Diversity in Buffalo Meat and Bowel from Traditional Market and the Sensitivity of Some Bacteria to Irradiation and Antibiotics
}

\author{
Harsojo $^{1^{*}}$ and S.Y. Sari ${ }^{2}$ \\ ${ }^{I}$ Center for Isotopes and Radiation Application, National Nuclear Energy Agency, \\ Jl. Lebak Bulus Raya No. 49, Jakarta 12440, Indonesia \\ ${ }^{2}$ Department of Biology, Faculty of Mathematics and Natural Sciences, University of Indonesia, \\ Depok, West Java 16424, Indonesia
}

\section{ARTICLE INFO}

\section{Article history:}

Received 4 October 2014

Received in revised form 24 April 2015

Accepted 11 May 2015

\section{Keywords:}

Bacteria

Buffalo

Initial contamination

Sensitivity

Irradiation

Antibiotic

\begin{abstract}
A B S T R A C T
The population of buffaloes in Indonesia was 1.37 million in 2012, representing an increase of $5.5 \%$ over its population the previous year. Buffaloes have been in Indonesia for such a long time, they have become a part of the lives of the majority of the Indonesian society. Research has been conducted to know the bacteria diversity in domestic buffalo meat and bowels from traditional markets in Pandeglang, Banten, in order to ascertain their safety based on their initial contamination and also to study the sensitivity of several of the bacteria to irradiation and antibiotics. The total bacterial was assessed by total plate count method as index of quality. The buffalo meat and bowel samples were taken from livers, intestines, lymph, lungs and tripe. Results showed that the contaminating bacteria were aerobic bacteria, coliform bacteria including Escherichia coli (E. coli), and Staphylococcus spp. in buffalo meat and bowel. The numbers of aerobic bacteria were in the $1.7 \times 10^{5}-2.3 \times 10^{6} \mathrm{CFU} / \mathrm{g}$ range, while the total coliform bacteria were in the $2.0 \times 10^{3}-6.8 \times 10^{4} \mathrm{CFU} / \mathrm{g}$ range. The total number of $E$. coli was in the $2.0 \times 10^{3}-6.0 \times 10^{4} \mathrm{CFU} / \mathrm{g}$ range, and Staphylococcus spp. was in the $2.0 \times 10^{4}$ $2.7 \times 10^{5} \mathrm{CFU} / \mathrm{g}$ range. No Salmonella was detected in any of the samples observed. The total coliform bacteria, E. coli, and Staphylococcus spp. in all buffalo meat and bowel samples exceeded the maximum numbers of microbes permitted by the Indonesian National Standard (SNI). The maximum of total coliform, E. coli, and Staphylococcus spp. permitted by SNI are $1.0 \times 10^{2}, 1.0 \times 10$ and $1.0 \times 10^{2} \mathrm{CFU} / \mathrm{g}$, respectively. The $\mathrm{D}_{10}$ values of $S$. aureus were in the $0.13-0.23 \mathrm{kGy}$ range, while for $E$. coli they were in the $0.07-0.13 \mathrm{kGy}$ range. The isolate of $S$. aureus from the lungs was the most resistant to cefoxitin, tetracycline, and amoxicillin antibiotics. The isolate of E. coli from buffalo bowels were almost sensitive to cefoxitin, tetracycline, and amoxicillin antibiotics.
\end{abstract}

(C) 2015 Atom Indonesia. All rights reserved

\section{INTRODUCTION}

The total buffalo population in Indonesia in 2012 was 1.37 million, which represented a $5.5 \%$ increase over the 2011 figure [1]. Buffaloes have been in Indonesia for a long time, so they are well adapted to the environment and have become a part of the lives of the majority of the Indonesia society. The increasing human activities cause a decrease in

*Corresponding author.

E-mail address: harsojo@batan.go.id

DOI: http://dx.doi.org/10.17146/aij.2015.381 buffalo population [2]. Buffaloes number fewer than cattle and buffalo meat is the second mostconsumed meat behind only beef [3]. It is known that buffaloes have advantages over other ruminants such as cows and goats. Buffaloes have a high natural adaptability (low mortality and high resistance to pathogen) and can live with lowquality feed $[4,5]$. In addition to producing meat and milk, buffaloes are also used to plow fields, pull carts, and complement traditional ceremonies. Buffalo meat has a unique taste compared to beef, while the buffalo skin can be used for crafts, 
especially for making drums [4]. In Tana Toraja, South Sulawesi, the buffalo has an important role in ritual ceremonies [6].

The buffalo meat and bowels which is consumed has a possibility to experience bacterial contamination which could be harmful for consumers. Generally, unlike cows, buffaloes are not slaughtered in slaughterhouses with good animal health control facilities. Quality assurance and security management may not be observed by the slaughterer, so the meat and bowels may be contaminated by microbes entering the blood circulation at the time of slaughtering. Subsequent contaminations can occur during preparation, such as during the division of carcasses, meat or bowels prior to distribution [7]. Bacteria which must not be present in meat and bowels are coliform groups such as Escherichia coli (E. coli), especially E. coli 0157 : $\mathrm{H} 7$, as they can cause hemorrhagic colitis. It is often found in water polluted by human waste [8]. Meat is a good medium for bacteria to grow. According to Anaya [9], more than $80 \%$ of food poisoning is caused by pathogenic bacteria. According to Tirtasujana and Gustiami [10,11], food poisoning can occur due to bacterial cross contaminations. Cross contaminations occur when bacteria from one contaminated food itemis transferred to another source which has not been polluted; the second source is usually a freshly-cooked food item. The contamination may occur due to improper food storage location.

The radioresistance of each strain of bacteria can be seen from its $D_{10}$ value. The higher the $D_{10}$ value is, the more radiation resistant the strain is. This $\mathrm{D}_{10}$ value can be used to eliminate those strains of bacteria [12].

The purpose of this work is to analyze the initial contamination which can affect the quality of buffalo meat and bowels and compare the common result with the results of previous studies. Additionally, this work also analyses the sensitivity of $S$. aureus and E. coli to gamma irradiation (from Co-60 source) and several antibiotics.

\section{EXPERIMENTAL METHODS}

\section{Materials}

The samples in this research are buffalo meat and bowels which were purchased from traditional markets in Pandeglang, Banten. Each sample was bought from a particular butcher with a repetition of three times.

\section{Determination of total aerobic bacteria}

The determination of total aerobic bacteria was conducted by using the surface plate method [13]. Twenty-five grams of samples was put into sterile peptone water $(225 \mathrm{ml})$ and was shaken thoroughly for 10 minutes. The total bacterial count was determined by streaking plate method on Nutrient Agar (NA). Incubation was carried out at $30{ }^{\circ} \mathrm{C}$ for $24-48$ hours.

\section{Determination of total coliform bacteria}

The determination of the number of coliform bacteria was conducted on MacConkey agar by using the pour plate method. The colonies were counted after 24-48 hours of incubation at $37^{\circ} \mathrm{C}$ [13].

\section{Determination of the number of bacteria E. coli}

The determination of the number of bacteria E. coli was performed using the EMB medium (from Oxoid) according to the method of Harsojo and Darsono [14].

\section{Determination of the number of Staphylococcus spp.}

The determination of the number of Staphylococcus spp. was done by using Baird Parker medium and incubation at $37{ }^{\circ} \mathrm{C}$ for 48 hours. The colonies were black and shiny with narrow white margins and surrounded at clear zones.

\section{Detection of Salmonella}

The presence of Salmonella was detected by using Tetrathionate Broth Base enrichment medium. A sample was weighed at $25 \mathrm{~g}$, then it was put into $225 \mathrm{ml}$ of enrichment medium and incubated at $37{ }^{\circ} \mathrm{C}$ for 24 hours. After 24 hours of incubation, one loop suspension was cultivated in selective media (XLD). The colonies were examined at $37{ }^{\circ} \mathrm{C}$ after 24-48 hours. The colonies were identified using biochemistry and serology test [8].

Radiation effects on the growth of S. aureus and E. coli

Those bacteria were isolated from buffalo meat and bowels and were grown to stationary phase in nutrient broth from Oxoid under aerobic 
condition for 16 hours at $30{ }^{\circ} \mathrm{C}$. The suspensions of the cells were prepared with same medium to give about $3 \times 10^{8} \mathrm{Cfu} / \mathrm{ml}$.For the study of the inactivation of $S$. aureus and E. coli in buffalo meat and bowels, $0.5 \mathrm{ml}$ samples of 16-h cultures in Nutrient Broth were transferred to each $5 \mathrm{~g}$ sample of buffalo meat or bowel which had been packed into polyethylene bags and pasteurized by exposure to $10 \mathrm{kGy}$ gamma rays. These samples were irradiated at $1.1 \mathrm{kGy} / \mathrm{h}$ at room temperature. The samples were irradiated to $0.1 ; 0.2 ; 0.3$ and $0.4 \mathrm{kGy}$. The number of viable cells was determined by counting viable colonies which developed after serial dilution of the irradiated samples with sterile peptone water $0.1 \%$ and incubation at $30{ }^{\circ} \mathrm{C}$ for $24-48$ hours on Nutrient Agar plates. The $\mathrm{D}_{10}$ value was measured by the method as used in the previous report [15].

\section{Sensitivity of S. aureus and E. coli to several antibiotics}

The sensitivities of $S$. aureus and E. coli were determined by several antibiotics such as cefoxitin, tetracycline, and amoxicillin. The antibiotics were in the form of discs (from Oxoid).

\section{RESULTS AND DISCUSSION}

The high ionizing ability of gamma rays with short wavelengths and high energies can cause chemical changes in bacteria. The chemical changes can inhibit the growth of the bacteria.

The total bacteria in buffalo meat and bowels showed in Table 1. Table 1 shows that the total of aerobic bacteria in buffalo meat and bowels were in the $1.7 \times 10^{5}-3.3 \times 10^{6} \mathrm{CFU} / \mathrm{g}$ range. The results of Harsojo's research [14] showed that the number of aerobic bacteria in meat was $1.7 \times 10^{7} \mathrm{CFU} / \mathrm{g}$, which was greater than the results obtained now and exceeded the limit that allowed by the Indonesia National Standard (SNI) [16]. According to SNI, the permissible limit of microbial contamination of animal origin is $1 \times 10^{6} \mathrm{CFU} / \mathrm{g}$ [16].

Table 1. The Number of Aerobic Bacteria in Samples of Buffalo Meat and Bowel (CFU/g)

\begin{tabular}{lcc}
\hline \multicolumn{1}{c}{ Sample } & \multicolumn{2}{c}{ Total Aerobic Bacteria } \\
\hline Outer Carcass Meat & $4.2 \times 10^{5}$ & \\
Inner Carcass Meat & $3.3 \times 10^{6}$ & $1.7 \times 10^{7} *$ \\
Liver & $1.7 \times 10^{5}$ & $1.2 \times 10^{6} *$ \\
Intestine & $2.0 \times 10^{5}$ & $2.3 \times 10^{6} *$ \\
Lymph & $4.2 \times 10^{5}$ & - \\
Lung & $3.4 \times 10^{5}$ & - \\
Tripe & $2.7 \times 10^{5}$ & - \\
SNI [15] & $1.0 \times 10^{6}$ & \\
Note : - no data; * Harsojo [14]
\end{tabular}

The total number of aerobic bacteria in the bowels, such as livers and intestines, of buffaloes are also lower compared with the results of previous studies. In all bowel samples, the numbers of aerobic bacteria are still below the limit that allowed by SNI [16]. These results demonstrate an increase in knowledge of hygiene so that the results obtained are now on average one order of magnitude lower.

This research also includes observations for coliform bacteria contamination in buffalo meat and bowel. Table 2 shows that the number of coliform bacteria found was in the $2.0 \times 10^{3}-6.8 \times 10^{4} \mathrm{CFU} / \mathrm{g}$ range. Based on the SNI [16] which sets the permissible limit of the concentration of coliform bacteria, one type of bacteria is often used as indicator of sanitation [17,18]. The use of coliform bacteria as indicator has an advantage in identifying any contamination in food and other materials, because they are more resistant than other bacteria during the processing and storage process $[17,19]$.

Therefore, the use of coliform bacteria detection techniques in the material is very important, as it indicates whether the material is fit for consumption or not. The presence of coliforms in food is undesirable because it means the material has been contaminated by human feces and possibly also contains other pathogenic bacteria [14,17]. The total numbers of coliform bacteria in buffalo meat and bowels are shown in Table 2.

Table 2 shows the number of coliform bacteria to be in the $2.0 \times 10^{3}-6.8 \times 10^{4} \mathrm{CFU} / \mathrm{g}$ range. Based on the SNI [16], the permissible limit of the concentration of coliform bacteria is $1.0 \times 10^{2}$ CFU/g. Thus all the materials tested samples have passed this requirement of the SNI. Compared with the results of a previous study by Harsojo and Darsono [14], it shows that the number of coliform bacteria in meat, livers and intestines found in this study is one order of magnitude lower. Compared with previous results, this result indicates that the slaughterers have given more attention to hygiene. The number of coliform bacteria in buffalo meat, livers, and intestines are lower than previously obtained results. However, the results of the number of coliform bacteria in meat and buffalo intestines was in the $2.0 \times 10^{3}-6.8 \times 10^{4}$ $\mathrm{CFU} / \mathrm{g}$ range, which exceeded the maximum number of coliform bacteria permitted by the SNI [16] which is $1.0 \times 10^{2} \mathrm{CFU} / \mathrm{g}$. 
Table 2. The Number of Coliform in Samples of Buffalo Meat and Bowel (CFU/g)

\begin{tabular}{lll}
\hline \multicolumn{1}{c}{ Sample } & \multicolumn{2}{c}{ Total Coliform Bacteria } \\
\hline Outer Carcass Meat & $5.0 \times 10^{3}$ & \\
Inner Carcass Meat & $6.8 \times 10^{4}$ & $4.2 \times 10^{5} *$ \\
Liver & $2.1 \times 10^{4}$ & $2.3 \times 10^{5} *$ \\
Intestine & $1.8 \times 10^{4}$ & $7.7 \times 10^{5} *$ \\
Lymph & $2.2 \times 10^{4}$ & - \\
Lung & $2.0 \times 10^{3}$ & - \\
Tripe & $2.2 \times 10^{4}$ & - \\
SNI [15] & $1.0 \times 10^{2}$ & \\
\hline Note : - = no data; ${ }^{*}$ Harsojo [14]
\end{tabular}

Table 3 shows the number of $E$. coli found in buffalo meat and bowel. The presence of $E$. coli in the meat and the bowels is undesirable because it indicates that the materials may have been contaminated with human feces.

In the latest foodborne illness in Germany which is caused by the E. coli bacteria, more than 3000 people were infected and 14 died. Technological developments lead which to changes in microorganisms and eating habits, as well as climate changes, has led to the generation of new strains such as pathogenic E. coli (E. coli $0157: \mathrm{H} 7)$. This strain is known to be capable of causing bleeding and horrendous wounds [20].

Table 3. The Number of E. coli bacteria in Samples of Buffalo Meat and Bowel (CFU/g)

\begin{tabular}{llc}
\hline \multicolumn{1}{c}{ Sample } & \multicolumn{2}{c}{ Total E. Coli Bacteria } \\
\hline Outer Carcass Meat & $4.0 \times 10^{3}$ & \\
Inner Carcass Meat & $6.0 \times 10^{4}$ & $2.0 \times 10^{4} *$ \\
Liver & $1.6 \times 10^{4}$ & $1.2 \times 10^{5} *$ \\
Intestine & $1.5 \times 10^{4}$ & $4.0 \times 10^{5} *$ \\
Lymph & $2.2 \times 10^{4}$ & - \\
Lung & $2.0 \times 10^{3}$ & - \\
Tripe & $1.3 \times 10^{4}$ & - \\
SNI [15] & $1.0 \times 10$ & \\
Note : - no data; * Harsojo [14]
\end{tabular}

Table 3 shows that E. coli bacteria were found in all samples. It indicates a poor hygiene management during the cutting and splitting process in and around slaughterhouses, thus increasing the risk of $E$. coli contamination. The number of E. coli bacteria in buffalo meat and bowels was in the $2.0 \times 10^{3}-6.0 \times 10^{4} \mathrm{CFU} / \mathrm{g}$ range. The highest number of bacteria $E$. coli contamination was found in inner carcass meat. This indicates the occurrence of the unhygienic process where meat and bowels are combined in one container, causing contamination.

In this experiment, also observed is the presence of Staphylococcus spp. contamination in buffalo meat and bowels. Although Staphylococcus spp. are not as dangerous as Salmonella, this bacterium can cause intoxication. It can causes foodborne illness if present in food. In the United States, there were reports of Staphylococcus poisoning which were symptomatic of intoxication.

According to Kartika et al. [17], each year, $20 \%$ to $50 \%$ of all poisonings are foodborne. In addition, Staphylococcus infections can cause symptoms such as boils, meningitis, osteomyelitis, pneumonia, and mastitis in humans and animals.

The numbers of Staphylococcus spp. in buffalo meat and bowels are shown in Table 4 . This Table shows that the total numbers of Staphylococcus spp. were in the $3.9 \times 103-2.7 \times 105$ $\mathrm{CFU} / \mathrm{g}$ range. The highest number of Staphylococcus spp. Contamination was found in outer carcass meat. All of the samples observed exceeded the allowed threshold of SNI [16]. Compared to Harsojo's observation in 2011 [14], the numbers of Staphylococcus spp. obtained in this study for inner carcass meat, livers and intestines were an order of magnitude higher.

Table 4. The Number of Staphylococcus spp. in Samples of Buffalo Meat and Bowel (CFU/g)

\begin{tabular}{llc}
\hline \multicolumn{1}{c}{ Sample } & \multicolumn{2}{c}{ Total E. Coli Bacteria } \\
\hline Outer Carcass Meat & $2.7 \times 10^{5}$ & \\
Inner Carcass Meat & $2.5 \times 10^{5}$ & $2.0 \times 10^{4} *$ \\
Liver & $1.2 \times 10^{5}$ & $1.9 \times 10^{4} *$ \\
Intestine & $3.0 \times 10^{4}$ & $2.0 \times 10^{4} *$ \\
Lymph & $2.0 \times 10^{4}$ & - \\
Lung & $3.9 \times 10^{3}$ & - \\
Tripe & $2.4 \times 10^{5}$ & - \\
SNI [15] & \multicolumn{2}{c}{$1.0 \times 10^{2}$} \\
\hline Note : - = no data; * Harsojo [14]
\end{tabular}

The high initial contamination of processed foods indicates that producers did not give adequate attention to the sanitation and hygiene of the food sold. Another possibility is that at the time of the transportation and retail in the seller's place, the transporters and the sellers are not concerned about food safety or are not familiar with the Hazard Analysis Critical Control Point (HACCP).

Salmonella was not found in any of the samples studied. However, it does not mean that meat and bowels were safe for consumption because the numbers of coliform bacteria, E. coli, and Staphylococcus spp. in the control with 0-week storage exceed the limits permitted by the SNI [16]. Extraordinary events which are caused by Salmonella and Staphylococcus foodborne illness are rarely reported in Indonesia. The percentage of the frequently-occurring outbreaks which are reported is still too low. 
Table 5 shows the $\mathrm{D}_{10}$ values of the $S$. aureus and E. coli isolates. The sensitivity of bacteria to irradiation is expressed by their $\mathrm{D}_{10}$ values. The $\mathrm{D}_{10}$ values of $S$. aureus in buffalo bowels varied from 0.13 to $0.23 \mathrm{kGy}$. The higher the $\mathrm{D}_{10}$ of a bacterium is, the more resistant to irradiation it is.

Table 5. $\mathrm{D}_{10}$ values of $S$. aureus and $E$. coli isolates

\begin{tabular}{lcc}
\hline \multirow{2}{*}{ Sample } & \multicolumn{2}{c}{$\mathrm{D}_{10}$ value $(\mathrm{kGy})$} \\
\cline { 2 - 3 } & S. aureus & E. coli \\
\hline Tripe & 0.16 & 0.07 \\
Liver & 0.14 & 0.13 \\
Outer carcass meat & 0.13 & 0.07 \\
Lymph & 0.13 & 0.10 \\
Lung & 0.23 & 0.11 \\
\hline
\end{tabular}

$S$. aureus is the most radiosensitive among the buffalo bowels such as outer carcass meat, lymph and liver. However, $S$. aureus was most resistant in the lungs, with a $D_{10}$ of $0.23 \mathrm{kGy}$. The $\mathrm{D}_{10}$ value in outer carcass meat and lymph was $0.13 \mathrm{kGy}$ and it seem not very much different from it is in the livers (0.14 kGy). The $\mathrm{D}_{10}$ value of E. coli in the buffalo bowels varied from 0.07 to $0.13 \mathrm{kGy}$. E. coli has the highest $\mathrm{D}_{10}$ value in livers $(0.13 \mathrm{kGy})$, while its $D_{10}$ value in tripe and outer carcass meat was $0.07 \mathrm{kGy}$. According to Harsojo et al. [8] the variation of the $D_{10}$ value is caused by the differences in the sensitivity of the type of bacteria that grow on the substrate, and the substrate composition mainly contributes to the sensitivity of the bacteria. $D_{10}$ values are very useful for the decontamination of bacteria. The ionizing ability of gamma rays with short wavelengths and high energies enables it to kill bacteria in large numbers by causing chemical changes in the bacterial cells. These chemical changes are an inhibitor of DNA synthesis; it interrupts the process of cell duplication and reproduction of bacteria [21].

Table 6 shows the sensitivity of $S$. aureus to several antibiotics. Isolates of $S$. aureus from tripe, livers, outer carcass meat, and lymph were sensitive to the typical antibiotics of tetracycline, amoxicillin, and cefoxitin. The sensitivity of $S$. aureus to cefoxitin varied from 28 to $36 \mathrm{~mm}$, while to amoxicillin and tetracycline its sensitivity varied from 36 to $42 \mathrm{~mm}$ and from 30 to $36 \mathrm{~mm}$, respectively. However, there is an isolate from the liver which exhibited an intermediate sensitivity level $(18 \mathrm{~mm})$, while the isolates originating from the lungs were resistant to the antibiotics, with sensitivities varying from 10 to $12 \mathrm{~mm}$.
Table 6. The sensitivity of $S$. aureus to several antibiotics (mm)

\begin{tabular}{lccc}
\hline \multirow{2}{*}{ Sample } & \multicolumn{3}{c}{ Antibiotic } \\
\cline { 2 - 4 } & Cefoxitin & Tetracycline & Amoxicillin \\
\hline Tripe & 30 & 36 & 36 \\
Liver & 36 & $18^{* *}$ & 42 \\
Outer carcass & 32 & 30 & 40 \\
meat & 28 & 30 & 36 \\
Lymph & $10^{*}$ & $10^{*}$ & $12^{*}$ \\
Lung &
\end{tabular}

- Resistent $* *$ Intermediate

Table 7 shows the sensitivity of $E$. coli to several antibiotics. The isolates originating from tripes, outer carcass meat, lymph, and lungs were sensitive to cefoxitin, varying in sensitivities from 22 to $34 \mathrm{~mm}$. It appears that all isolates were sensitive to tetracycline, ranging from 20 to $34 \mathrm{~mm}$. However, there is one isolate, originating from the liver, which was resistant to amoxicillin $(8 \mathrm{~mm})$; another isolate, originating from the tripe, is in the intermediate group $(18 \mathrm{~mm})$. The rest can be classified into the amoxicillin-sensitive group with sensitivities varying from 20 to $34 \mathrm{~mm}$. The results of the measurements of the sensitivity of bacteria to antibiotics show that $E$. coli was more sensitive than $S$. aureus to antibiotics. In Indonesia, irradiated foods have been commercialized, although limited to exports to several countries or regions such as Europe, the United States, and the Middle East. The commercialization of irradiated foods is regulated by the Regulation of the Minister of Health of the Republic of Indonesia No. 701/MENKES/PER/VIII/2009, the Indonesian food law, the Regulation of the Government of Indonesia No. 69/1999 article 34 regarding food labeling and advertisement, and regulations of international trade on commercialization. The Hazard Analysis Critical Control Point (HACCP) has to be applied, and if the initial contamination is found to exceed the maximum number of microbes permitted by the Indonesia National Standard, gamma irradiation can be used to eliminate those microbes.

Table 7. The sensitivity of $E$. coli to several antibiotics (mm)

\begin{tabular}{llcc}
\hline \multirow{2}{*}{ Sample } & \multicolumn{3}{c}{ Antibiotic } \\
\cline { 2 - 4 } & Cefoxitin & Tetracycline & Amoxicillin \\
\hline Tripe & 32 & 22 & $18^{* *}$ \\
Liver & $10^{*}$ & 20 & $8^{*}$ \\
Outer carcass & 22 & 22 & 20 \\
meat & 34 & 34 & 34 \\
Lymph & 28 & 28 & 24 \\
Lung & &
\end{tabular}




\section{CONCLUSION}

The total number of aerobic bacteria, total coliform bacteria, the number of $E$. coli, and the number of Staphylococcus spp. were obtained to be lower than in the results of previous works. The total coliform bacteria, E. coli, and Staphylococcus spp. in all buffalo meat and bowel samples exceeded the number of microbes permitted by the Indonesia National Standard (SNI). Salmonella was not found in any of the samples studied. The $\mathrm{D}_{10}$ values of $S$. aureus were in the $0.13-0.23 \mathrm{kGy}$ range, while for $E$. coli, the values were in the $0.07-0.13 \mathrm{kGy}$ range. The isolate of $S$. aureus from the lungs was the most resistant to cefoxitin, tetracycline, and amoxicillin antibiotics. The isolate of $E$. coli from buffalo bowels were almost sensitive to cefoxitin, tetracycline, and amoxicillin antibiotics. In general, all species of bacteria have different sensitivity to radiation and antibiotics. Gamma irradiation can be used to eliminate pathogenic bacteria with known $D_{10}$ values. Also, gamma irradiation can reduce the total number of bacteria from samples to below the limits permitted by the Indonesian National Standard.

\section{ACKNOWLEDGMENT}

The authors gratefully acknowledge Mr. Armanu and Mr. Bonang from CAIR for their excellent assistances in this work.

\section{REFERENCES}

1. Anonymous, General Directorate of Animal Husbandry, http://ditjennak.deptan.go.id/index. php? page $=$ statistik\&action=info\&idcat $=1$. Retrieved in October (2013).

2. Sulaeman, Increasing Population and Quality of Buffalo through Reproductive Efficiency, Proceeding of National Seminar and Workshop of Buffalo (2010) 16. (in Indonesian)

3. D. Santoso and E. Tuhwerkih, Increasing Land Management to Enhance Ruminant Development, Proceeding National Seminar on Husbandary Technology and Veterinair (2003) 258. (in Indonesian)

4. M.A. Fadillah, Buffalo and Banten People: An Ethnohistory Perspective, Proceeding in National Seminar and Workshop of Buffalo (2010) 23. (in Indonesian)

5. H. Nuraini, E. Andreas and C. Sumantri, Carcass Characteristics of Swamp Buffalo in
Pandeglang District, Banten, Proceeding of National Seminar and Workshop of Buffalo (2010) 31. (in Indonesian)

6. M. Sariubang, D. Pasambe and A. Ella, Reproduction and Production of Buffalo Mud in Tana Toraja District, South Sulawesi, Proceeding National Seminar on Husbandary Technology and Veterinair (2003) 60. (in Indonesian)

7. Soeparno, Meat Technology and Science (in Indonesian: Ilmu dan teknologi daging), $2^{\text {nd }} e d$. Gajah Mada University Press, Yogyakarta (1994) 202.

8. Harsojo and Z. Irawati, Journal of Nuclear Technology Ganendra $14 \quad$ (2011) 96. (in Indonesian)

9. M. Anaya, http://www.newsmedical.net. Retrieved in March (2015).

10. D.R. Tirtasujana, http://tirtasujana.com. Retrieved in March (2015).

11. E. Gustiami, Journal of Research Development Agriculture 28 (2009) 96. (in Indonesian)

12. E. Asragani, Resistance Mechanisms in Radioresistant Bacteria: Survival Secret in Radioresistant Bacteria. Retrieved in April (2015).

13. I. Kadir and Harsojo, Journal for the Applications of Isotopes and Radiation 5 (2009) 118. (in Indonesian)

14. Harsojo and Darsono, Journal for the Applications of Isotopes and Radiation 9 (2013) 129. (in Indonesian)

15. Harsojo and L.S. Andini, Decontamination of Some Pathogenic Bacterias on Swamp Buffalo Meat and Bowel by Gamma Irradiation, Proceeding of National Seminar and Workshop of Buffalo (2010) 116. (in Indonesian)

16. Anonymous, Bacteria and Heavy Metal Contamination in Food, Indonesian National Standard, Jakarta (2009).

17. E. Kartika, S. Khotimah and A.H. Yanti, Journal Protobiont 3 (2014) 111. (in Indonesian)

18. K.L.R. Mansauda, Fatimawati and N. Kojong, Journal Pharmacon 3 (2014) 2302. (in Indonesian)

19. A. Munif, Environmental Sanitation Journal 3 (2014) 1. (in Indonesian)

20. M.L. Bari and Y. Inatsu, Escherichia coli 
0157:H7, in: Encyclopedia of Food Microbiology, $2^{\text {nd }}$ ed. Retrieved in March (2015).
21. G. Septiandina, http://gusti0909.wordpress.com /2010/01/12/inhibitorenzim. Retrieved in April (2015). 